\title{
The Pandemic from an Aesthetic Perspective-Towards a Beautiful Artistic Life in Difficult Situations
}

\section{美学视角下的疫情一一在困境中走向艺术化的美好生活}

\author{
Cheng Yang \\ Shanghai Maritime University, China
}

\begin{abstract}
The sudden outbreak of Covid-19 epidemic is an unprecedented battle for mankind, in which the sublimity and greatness of the human nature of medical workers in the frontlines from all countries is seen clearly from their brave devotion to the rescue of the infected. It is also an indication of the real concerns and attitudes as well as the abilities of the politicians of all countries in their dealing with emergencies. For most ordinary people, they also dramatized an interesting life play to the world. We are surprised to find out how much artistic people and people who are accompanied by art can bring to the world at this critical period of time. Their passion for artistic quality life has inspired countless lives. Art is not only the real record and representation of human history and life, sublimation of their spirit can also become a daily life mode of human beings, apart from the pursuit of materialism. At this special period when life is threatened by the virus, the desire of human beings to pursue and experience the spirit and even the spiritual space is becoming stronger and stronger. This disaster has brought us the opportunity of life reflection and the hope of rebirth. This paper tries to tell people that to live artistically while quarantining at home is not only what people at present are pursuing but also the long-term aspiration of life for the future.
\end{abstract}

Keywords: human nature, beauty, art, life, COVID-19

\section{摘要}

此次突如其来的疫情，是人类一场空前绝后的战役，在这次战役中不仅非常鲜活地展现 出前线各国医务工作者们人性中的崇高与伟大、非常集中地展示了各国政要们的真实态 度和能力，而对于大多数普通人而言，也极具戏剧化地向世界展演了一出耐人寻味的人 生大戏。这其中我们惊喜地发现，那些以艺术为伴的民族和人群此时带给全世界多么可 贵的生命热情，深深地鼓舞了无数生命。艺术不仅是人类历史和生活的真实记录和再现 升华，也可以成为人类日常的一种生活模式，随着人类对物质的追求已经到达一个瓶颈 阶段，人类对精神甚至是灵性空间的追求和体验的欲望会愈来愈强烈。疫情虽然致人类 于灾难之中，但却给我们带来了反思的契机和重生的希望。本文试图从美学和艺术的角 度去阐释，创造艺术化的生活不仅是疫情期间，留守家中的一种完美的生活状态，而且 也是中国未来全民族共同追求的生活理想。

关键词 : 人性、美、艺术、生活、新冠肺炎病毒 


\section{Talking about People in the Pandemic}

In March, when the spring forest was in full bloom, a pandemic trapped us. Is it true life or is it a gradual progression toward withering? Sealed inside, we begin thinking about the noise and impatience of past life and are finally being forced to face the current loneliness. People usually think hard after encountering sudden shocks and are shocked to discover the meaning of life originally. The same is true of a city and a country. In this sudden pandemic, nature has placed us in our own homes, and we have all been exiled to the cubbyhole.

When I read Xun's (2012) verse, I suddenly realized the many beautiful things in life that had been taken for granted in the past, but now I have been illuminated: "How lucky I am to hear the voice of beauty, those The bright birds of the birds, those frogs ... how lucky I am to see beautiful things, to see a wild ginger flower slowly blooming in the humid air ... how lucky I can smell a new season opening The sweet fragrance of sweet-scented osmanthus ... how lucky I can touch such a fine texture of a leaf ... how lucky I can be to taste the taste of life, in a strong drink, recall the bitterness, bitterness, sweetness of life, In a faint cup of spring tea, I know that life can be so clear that there is no entanglement. And the premise of feeling all this beauty is 'alive'. Only alive can you hear, see, smell, touch, Taste to ..." (page 3).

An epidemic, so much life and death, so many vicissitudes of life. In just only a few days, there were thousands of deaths. How many still have time to formally say "goodbye" to the world and then die quietly? Occasionally, only words are left, people outside the city choke in pain. Guoping Zhou (2012) said, "Take care of your life, settle your heart, and your life is complete" (page 1). When an epidemic strikes, it shows how fragile human life is, its vulnerability, and it leaves a permanent scar. Albert Camus (1947/2016) described this in The Plague (Figure 1), "Along with these recent days of upsurges, there is also a rising number of deaths of about 700 people a week. The whole city has been frustrated. Shrouded. In this area, people usually used to be at the door. Now all the doors are closed and the shutters are closed. No one knows whether this is to isolate the plague or to block the heat wave. But groans still came from the room. When this happened, people would gather in the street curiously to listen, but now after a long period of panic, people have become hard-hearted, even if you hear the groans. And still go my own way, live my own life, Think of it as a sparse and ordinary language ..." (page 134). At the beginning of this coronavirus pandemic, there was a huge gap between the medical resources and the number of patients. Many patients are left to their fate without timely help and there are also onlookers who become abnormal or silent because they hear and witness too much sadness. In such a situation, No one has the right to judge whether it is right or wrong, just let nature take its course. One can only judge one's own humanity when one is really facing death. The doctors and nurses are similar to the captain and sailors in the movie "Titanic" when the ship was about to sink. Although they are doing their best, the number of people who can be carried on the lifeboat is limited. When the majority of passengers are forced to face death, all kinds of human extremes come into play, and perhaps a similar story happened in the epidemic town in a certain period of time. Wuhan writer 
Fang Fang wrote in her Feng Cheng Diary, "It's gone, the living is like that, I wish we could have memories."

Speaking of memory, I am transported back to 2002, when SARS first appeared. It is so ironic and quite absurd that the virus came again with a "new coat" after some time. In 2017, Shi zhengli said in her research: "Although SARS has not made a comeback for so many years, in nature, this virus similar to SARS still exists. If we humans are not alert, then next time the virus infection may be a direct infection, or it may infect humans through other animals". As soon as this speech, 2019 Spring Festival "this possibility" really materialized.

Scientific research tells us that viruses are not the product of today, but have evolved over many years, or even tens of thousands of years, with their natural hosts. They do not come for human beings. They also follow the laws of nature to evolve for their own survival. Everything in the universe following the rules of its "tao" could have been harmonious and secure. However, human beings cannot help but be tempted and constantly eat the "forbidden fruit," causing disasters. Statistical analyses performed by scientific researchers showed that $70 \%$ of the newly transmitted viruses come from animals, for example, Bats were the source of the SARS virus, but the stage for its development is the wildlife market and restaurants. Without humans hunting civets and eating civets, the transmission chain from bats to civets to humans would not have happened and SARS would not have exploded No trade, no killing. Some people under the trend of interest, can violate the principles of heaven, ignore the law, and even sell human nature.

\section{Talking about Beauty in the Pandemic}

In the 1830s, Zhu (2012), a well-known Chinese aesthetician, wrote in his correspondence collection Talking about Beauty, "Talking about beauty, this is very sudden! In this critically dying year, I still have heart and soul Come to 'talk about the wind moon'? Yes, I am talking about beauty now, precisely because the timing is too urgent .... I firmly believe that emotion is more important than reason. To cleanse the heart, we must start with 'Emotional Love', must In addition to eating warm clothes, high-ranking officials, high-ranking officials, etc., there should be no noble and purer requirements. Purification of life, beautification of life ... This world is only a dense and seamless network of interests. In terms of interests, people The most difficult to coordinate, everyone puts themselves first, and the crimes of fraud, abuse, and robberies are rooted in it" (page 114). These words were written a century ago, during the age of internal and external troubles and smoke-filled war. One hundred years later, today, China and the rest of the world are facing an even more terrible war - a war with heavy casualties. The brilliance and ugliness of human nature are always obvious at such times. No matter what kind of war, there will always be an ugly skin bag to make a fortune by the national disaster, but there will always be a noble soul who died for the country, gave up life and forgot to die. Although the years are not the same as before, the human heart seems to have known each other. This time, the virus that has almost swept the world, 
in each country, but it let us witness the power of humanity. It is the radiance of human nature that these people illuminate and warm the world.

In the book Talking about Beauty, Zhu (2012) vividly explained "three attitudes to an ancient pine", which represents three typical and very different values. "If you are a wood merchant, I am a plant scientist and another friend is a painter. The three of them watched this lesson Gu Song at the same time. The three of us can all say that we are 'perceived' to a tree at the same time, but the 'perceived' by the three is actually three. A different kind of thing" (page 118). The wood merchant cannot be separated from the habit of a businessman. In his eyes, this tree is a pile of wood worth money. $\mathrm{He}$ is figuring out how to cut it, transport it, and sell it; a botanist cannot get away. As a scientist's habit, what he perceives is that the leaves of this tree are needle-like, the fruit is spherical, and the plant is evergreen. Considering it belongs to a certain family; the artist only cares about aesthetics, and what he perceives is a green and vigorous old tree. The vigorous old tree watched its verdant color intently, curled like a dragon and snake's texture, and it stood upright and indomitable. The ancient pine image seen by different people is a reflection of personal character, attitude, and accomplishment.

What kind of contrast will these three attitudes have in real life? Businessmen use "practical" as a measure of value and standard for things. There is nothing wrong with it since ancient times. According to text archeologists, why is the "Chinese" (Figure 2) the earliest Chinese character? In the oracle, does it appear as a "goat" above and a "big" below? As it turned out, In the early days of human society, "sheep" was used as a kind of equivalent exchange, the larger the sheep, the more things they could change back, so people's hearts are naturally happy, think that the bigger the sheep, the better, the bigger the more beautiful. At first, people's aesthetic sense is not from taste, vision, but from people's actual feelings of life, it can be said that in the early human society, everyone is commercial, From the perspective of the people at that time, it was good and righteous not to steal sheep, not to rob sheep or to exchange sheep fairly. This kind of good, righteousness is the basis of people can exchange, can also be said to be the basis of the aesthetic sense of life, beauty, good and righteousness are trinity. So whether we can understand this: practical attitude to good for the highest purpose, the rational use of good is righteousness. The so-called gentleman takes money youdao, whether can be interpreted like this: "good" is equivalent to "wealth"; and "Tao" is equivalent to "righteousness", from the origin of the word "beauty", they are mixed, closely linked.



FIGURE 1 | Calligrapher Yankai write the word "beauty" of oracle. 
The reason why we encounter something that is not "beautiful" today is that some people just want to "use" and discard the original business attitude of why people are "beautiful". Meanwhile, the word "beauty" also explains that sheep has a close relationship with human daily life since the ancient times. It is a common and prolific animal in human life. Its meat can be eaten and its fur can be used to protect against cold. Early humans killed it, eat it, and use it, but they do not forget to be grateful for it. Our ancestors worshiped the sheep as a totem worship. Aside from the sheep-shaped pottery unearthed from the Yangshao Cultural Site (Figure 2), our ancestors also used it as a sign of beauty and dress themselves up with it, much like what we call fashion today. We have to admire how noble and sacred this primitive pragmatism and attitude towards animals are. We have to admire this primitive pragmatism and the attitude towards animals, which is noble and sacred human behavior. It's a shame.

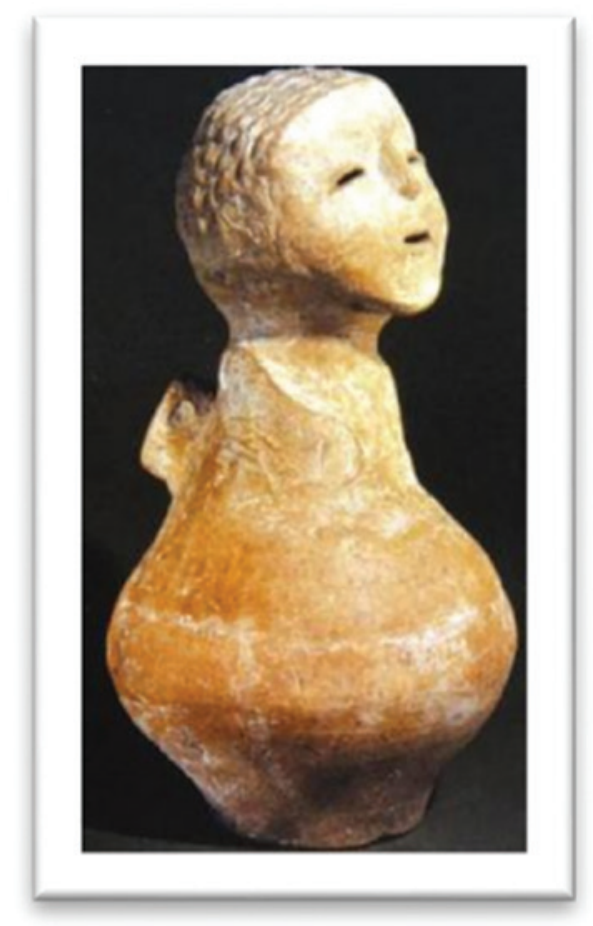

FIGURE 2 | Sheep-shaped pottery from the Yangshao CulturalSite. https://news.gujianchina.cn/show-3764.html.

\section{Talking about Art and Life in Pandemic}

The history of human civilization, ancient and modern, Chinese and foreign, tells us that when the material life of humans has reached a saturation level relative to this era and people have a certain amount of leisure time at the same time, it must be a prosperous era of artistic development. Shells, teeth, bones, and other parts of animals left were used as decorations for beautification; paint made of animal blood and rock 
powder was used to paint on caves or rock walls. These works of art in the early days of human society, very simple and alive, showed a vibrant state of primitive life to the later generations of human beings.

Then to the slave society, feudal society ... almost every society that has reached a relatively economically prosperous period, it is also a golden moment for its artistic prosperity. In today's China, most people are physically richer than ever before, but polls show that people's happiness index is extremely low, especially for the middle class and those living in cities. Meanwhile, those at the bottom of society have a sense of happiness. The fast, mechanical modern life model has turned people into a clock, always in a state of excitement, only work, no leisure.

With this sudden emergence of a new coronavirus, all busy people had to stop and have leisure time. However, for people who are used to being busy, it is not easy to suddenly lock up and stay at home. Chuang Tzu said: "There is no noblest man than he who is alone" https://baike.so.com/doc/2744006-2896048.html (the first message).

A person's best condition is to enjoy the prosperity, but also to settle down a person's time With the continuous development of social material wealth and technology and "aging" trend, more and more people will have "leisure time" or "one person's time" in the future. Whether from the perspective of the development of the entire social civilization or from the perspective of individual self-improvement, it will be well. To get along with yourself, to enjoy themselves in the world of self, not to cause unnecessary burdens on society, it is a very important thing for personal happiness and social security and prosperity, Especially in the current special period of global epidemic prevention and control, it is more important.

Thousands of years ago, during Western Zhou Dynasty, Zhou Gong used "rituals and festivities" to establish and spread customs, instigate the people, and achieve the purpose of governing the country. It is recorded in the Book of Rites: "To seek but not to be interested, to steal and steal but not to do, so that the door and not to close, is called Datong." This is what we later called the "night close", which shows that the social order and morality at that time were extremely good. Art can not only heal the heart and reconcile it with the outside world, but it can also govern society and unite the world. Looking at the impact of the novel coronavirus on people's lives, it will also bring us a benefit - allowing most people sufficient time to think about the meaning of life and rearrange our own life. Either lonely or vulgar, what can trap people is often a gully in the heart. When art is embedded in the bits of life, the outlier does not feel lonely, and the living will not Tasteless. At this moment-spring, gathered outside the window; dilemma, rebirth in the absolute best.

\section{About the Author}

Cheng Yang, director and associate professor of art education center of Shanghai Maritime University. Master degree from Shanghai Normal University Conservatory of Music dance education major. At present, she is also a special professor of Shanghai Zhenghe Research Center. She has published many papers on marine art and belief. She is the first scholar in domestic universities to study marine culture and belief from the 
perspective of dance art. At the same time, she is also the Board member of IACASE (International Association of Creative Arts Somatic Education) China committee, focusing on dance healing and ecological healing interaction and combination of further pioneering research and contribution.

\section{References}

Camus, A. (1947/2016). The Plague (R. Zhang, Trans.). Anhui, China: Anhui Literature and Art Publishing House, pp. 134.

Li, Z. (2002). Chinese aesthetics. Tianjin, China: Tianjin Academy of Social Sciences Press.

Shi, Z. (2017). Discovery of a rich gene pool of bat SARS related corona viruses provides new insights into the origin of SARS corona virus. PLoS Pathogens.

Xun, J. (2012). Letter to young artists. Beijing, China: Xinzhi Sanlian Bookstore Press, pp. 3.

Zhu, G. (2012). Talking about beauty. Beijing, China: Xinzhi Sanlian Bookstore Press, pp. 118. 